\title{
FIRST RECORD OF HYLASTES OPACUS ERICHSON AND CRYPTURGUS HISPIDULUS THOMSON, C. G. (COLEOPTERA; CURCULIONIDAE; SCOLYTINAE) FOR THE TURKISH FAUNA
}

\author{
KUMBAŞLI, M. ${ }^{1}-$ HIZAL, E. $^{2}-$ ACER, S. $^{2}-$ ARSLANGÜNDOĞDU, Z. ${ }^{2 *}-$ ADAY KAYA, A. G. ${ }^{3}$ \\ ${ }^{1}$ Department of Wildlife Ecology and Management, Faculty of Agriculture and Natural \\ Sciences, Abant Izzet Baysal University, Bolu, Turkey \\ ${ }^{2}$ Department of Forest Entomology and Protection, Faculty of Forestry, Istanbul University- \\ Cerrahpaşa, Istanbul, Turkey \\ ${ }^{3}$ Yenişarbademli Vocational School, Applied Sciences University of Isparta, Isparta, Turkey \\ *Corresponding author \\ e-mail: zeynel@istanbul.edu.tr; phone:+90-212-338-2400/ext. 25256; fax: +90-212-338-2424 \\ (Received $21^{\text {st }}$ May 2018; accepted $11^{\text {th }}$ Jul 2018)
}

\begin{abstract}
Scolytinae subfamily (Coleoptera: Curculionidae) is represented by 135 species in Turkey including 8 species of the genus Hylastes Ericson and 7 species of the genus Crypturgus Ericson. A total of 79 adult individuals of Hylastes opacus Erichson and 6 adult individuals of Crypturgus hispidulus Thomson, C. G. were obtained from log and pheromone traps in pine stands at twelve localities during 2014. H. opacus and C. hispidulus were recorded for the first time in Turkey. H. opacus were obtained from trap logs of Pinus brutia and Pinus nigra and also pheromone traps in P. brutia stands. Adult individuals of $C$. hispidulus were observed in association with Orthotomicus erosus and Pityogenes pennidens on P. brutia and $P$. nigra log traps.
\end{abstract}

Keywords: Hylastes opacus, European bark beetle, Crypturgus hispidulus, Pinus brutia, Pinus nigra, Marmara, Turkey

\section{Introduction}

The Scolytinae subfamily (Coleoptera: Curculionidae) is one of the largest groups of Coleoptera and it is represented by 135 species in Turkey (Wood and Bright, 1992a, b; Knížek, 1998; Selmi, 1998; Sarıkaya and Avc1, 2011; Sarıkaya 2013; Sarıkaya and Knížek, 2013; Cognato, 2015; Lieutier et al., 2016). The majority of species feed on dead or dying tissues and are not normally considered to be of an economic importance. However, such species can become economically important if their galleries create holes in timber used for furniture or veneer, or if they transport pathogenic fungi to living trees during the feeding period by young adults to mature the gonads. The relatively small number of species that attack living trees, saplings or seedlings, or the seeds of commercial crops are sometimes of major economic importance, causing damage estimated in millions of dollars (Knížek and Beaver, 2007).

Species of the genus Hylastes Ericson primarily colonize subterranean stem parts of various conifers, predominantly, Pinus, Picea and Abies genera. The genus Hylastes has 21 species in conifers throughout the Holarctic region (Webber and Gibbs, 1989; Bright, 2014). It is presented with eight species in Turkey; $H$. angustatus (Herbst,), $H$. ater (Paykull), H. attenuatus Erichson, H. batnensis anatolicus Knížek \& Pfeffer, H. brunneus Erichson, H. cunicularius Erichson, H. linearis Erichson and H. substriatus Strohmeyer (Selmi, 1987; Wood and Bright, 1992a; Lieutier et al., 2016; Alonso- 
Zarazaga et al., 2017). Their adults feed on the tender bark near the root collars of seedlings and transplants, often girdling them, the species is frequently considered a noxious pest of nurseries and pine plantations, not only killing small plants but exposing older trees to infestation by wound parasites such as Fomes (Basidiomycetes, Polyporales: Polyporaceae) (Hoebeke, 1994). Hylastes species are also the vector of black stain root diseases and some of them have been reported as serious pests in forestry (Webber and Gibbs, 1989).

The genus Crypturgus Erichson breed in conifers throughout the Holarctic region and fifteen species are currently recognized (Wood and Bright, 1992a; Jordal and Knížek, 2007). It is represented with 7 species in Turkey; C. cinereus (Herbst), $C$. cylindricollis Eggers, C. dubius Eichhoff, C. mediterraneus Eichhoff, C. numidicus Ferrari C. parallelocollis Eichhoff and C. pusillus (Gyllenhal) (Wood and Bright, 1992a; Selmi, 1998; Lieutier et al., 2016; Alonso-Zarazaga et al., 2017). Species of the genus Crypturgus have very small body size $(0.9-1.5 \mathrm{~mm})$ and inhabit bark of the trees. The species are very abundant throughout the whole Mediterranean basin, but largely secondary, infesting only trees heavily stressed or already infested by more aggressive species. They have no economic relevance; high population density of this species may interfere with the development of associated more aggressive species (Lieutier et al., 2016).

In the current study Hylastes opacus Erichson and Crypturgus hispidulus Thomson, C. G. were reported for the first time to Turkish fauna.

\section{Material and methods}

Specimens of $H$. opacus and $C$. hispidulus were collected from trap logs and pheromone traps in stands of Pinus brutia Ten. and P. nigra J. F. Arnold in Marmara Region, Turkey (Fig. 1).

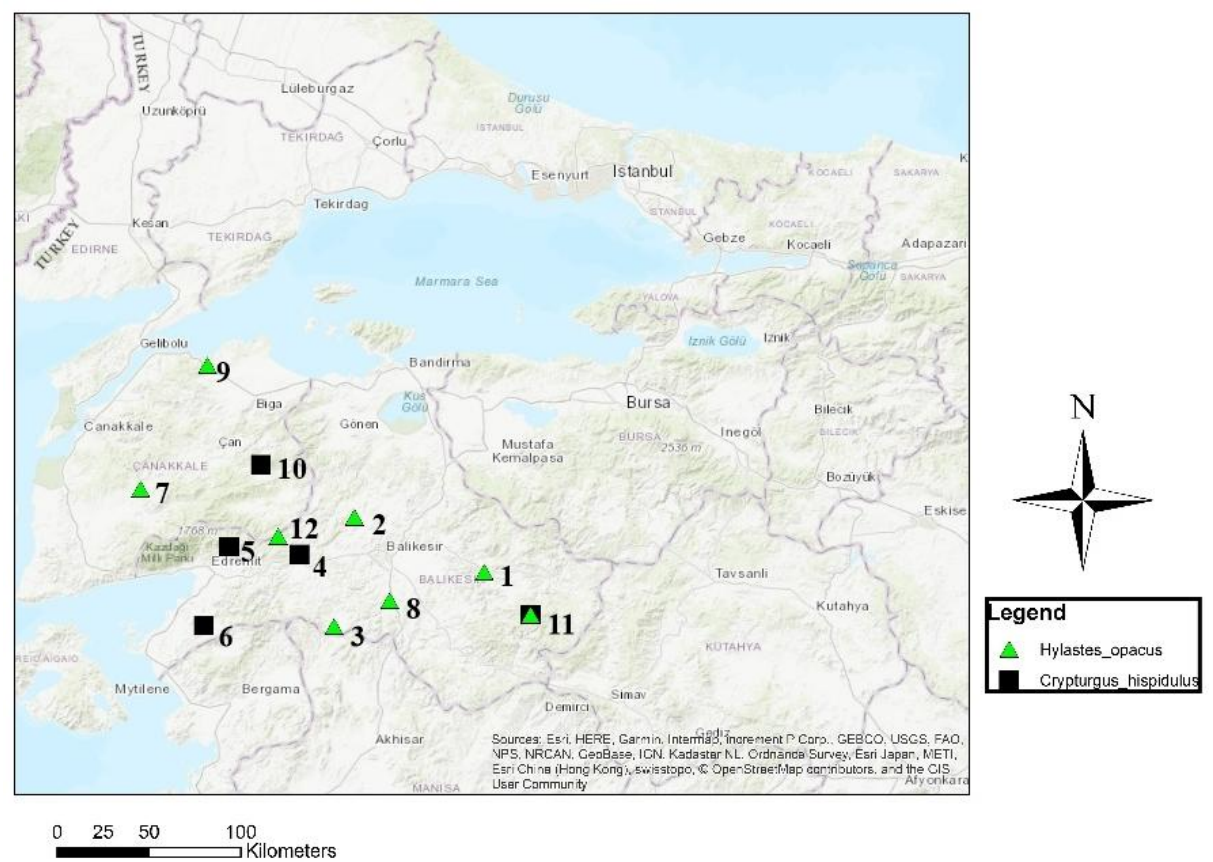

Figure 1. Collection sites 
Pheromone traps baited with the pheromone of Orthotomicus erosus Wollaston and trap logs were set up in February 2014 in 12 sites. Coordinates of the collection sites and trap types are presented in Table 1. Traps were checked for the presence of beetles at regular intervals. Insects were collected and identified on the basis of characteristic morphological features of the elytra and elytral declivity by using a LEICA S8APO stereomicroscope. Taxonomic keys in (Grüne, 1979; Wood, 1982; Hoebeke, 1994; Jordal and Knížek, 2007) were used to determine the specimens. Color photographs of specimens were prepared by using the stereomicroscope with a LEICA DFC295 digital video camera. Voucher specimens of $H$. opacus and $C$. hispidulus were prepared appropriate methods and preserved at Istanbul University-Cerrahpaşa, Faculty of Forestry, Department of Forest Entomology and Protection.

Table 1. Coordinates of the collection sites and trap types

\begin{tabular}{c|c|c|c|l}
\hline Locality (N) & Geographical positions & Altitude (m) & Trap type & Host plant \\
\hline $\mathbf{1}$ & $39^{\circ} 34^{\prime} 46.6^{\prime \prime} \mathrm{N} ; 28^{\circ} 21^{\prime} 42.1^{\prime \prime} \mathrm{E}$ & 508 & Log trap & P. brutia \\
$\mathbf{2}$ & $39^{\circ} 46^{\prime} 52.1^{\prime \prime} \mathrm{N} ; 27^{\circ} 43^{\prime} 33.5^{\prime \prime} \mathrm{E}$ & 448 & Log trap & P. brutia \\
$\mathbf{3}$ & $39^{\circ} 22^{\prime} 07.0^{\prime \prime} \mathrm{N} ; 27^{\circ} 37^{\prime} 34.9^{\prime \prime} \mathrm{E}$ & 275 & Log trap & P. brutia \\
$\mathbf{4}$ & $39^{\circ} 38^{\prime} 26.2^{\prime \prime} \mathrm{N} ; 27^{\circ} 27^{\prime} 25.7^{\prime \prime} \mathrm{E}$ & 310 & Log trap & P. brutia \\
$\mathbf{5}$ & $39^{\circ} 40^{\prime} 15.3^{\prime \prime} \mathrm{N} ; 27^{\circ} 06^{\prime} 43.5^{\prime \prime} \mathrm{E}$ & 372 & Log trap & P. brutia \\
$\mathbf{6}$ & $39^{\circ} 22^{\prime} 19.5^{\prime \prime} \mathrm{N} ; 26^{\circ} 59^{\prime} 19.8^{\prime \prime} \mathrm{E}$ & 311 & Log trap & P. brutia \\
$\mathbf{7}$ & $39^{\circ} 53^{\prime} 11.2^{\prime \prime} \mathrm{N} ; 26^{\circ} 40^{\prime} 44.9^{\prime \prime} \mathrm{E}$ & 287 & Log trap & P. brutia \\
$\mathbf{8}$ & $39^{\circ} 27^{\prime} 58^{\prime \prime} \mathrm{N} ; 27^{\circ} 53^{\prime} 57^{\prime \prime} \mathrm{E}$ & 225 & Pheromone trap & P. brutia \\
$\mathbf{9}$ & $40^{\circ} 20^{\prime} 59.8^{\prime \prime} \mathrm{N} ; 27^{\circ} 00^{\prime} 24.3^{\prime \prime} \mathrm{E}$ & 133 & Log trap & P. brutia \\
$\mathbf{1 0}$ & $39^{\circ} 58^{\prime} 41.6^{\prime \prime} \mathrm{N} ; 27^{\circ} 16^{\prime} 6.2^{\prime \prime} \mathrm{E}$ & 93 & Log trap & P. brutia \\
$\mathbf{1 1}$ & $39^{\circ} 24^{\prime} 47.9^{\prime \prime} \mathrm{N} ; 28^{\circ} 35^{\prime} 18.6^{\prime \prime} \mathrm{E}$ & 1164 & Log trap & P. nigra \\
$\mathbf{1 2}$ & $39^{\circ} 42^{\prime} 34.9^{\prime \prime} \mathrm{N} ; 27^{\circ} 21^{\prime} 09.3$ "E & 730 & Log trap & P. nigra \\
\hline
\end{tabular}

\section{Result and discussion}

A total of 79 adult individuals of $H$. opacus and 6 adult individuals of $C$. hispidulus were collected during 2014 from eight localities in Turkey at various altitudes between 93 and $1164 \mathrm{~m}$ (Table 1). The number, locality and date of captured $H$. opacus and $C$. hispidulus are given in (Table 2).

H. opacus can be distinguished from other Turkish species of the genus Hylastes by frons without longitudinal ridge (Grüne, 1979; Freude et al., 1981). Its adults were 2.5-3 $\mathrm{mm}$ long and were recognized by the following combination of characters: frons and vertex closely and coarsely punctured; pronotum as long as wide and constricted anteriorly; interstriae flat, wider than striae; elytral declivity with filiform setae; and body black with antennae and legs reddish brown and elytra dull (Fig. 2).

The distribution area of $H$. opacus includes; Austria, Belgium, Bulgaria, China, Denmark, England, Estonia, Finland, France, Germany, Greece, Hungary, Ireland, Italia, Japan, Korea, Latvia, Lithuania, Macedonia, Norway, Poland, Russia, Slovakia, Slovenia, Sweden, Switzerland, North America and Canada (Wood and Bright, 1992a; GBIF, 2017; Fauna Europaea, 2018). 
Table 2. Locality, capturing date and individual numbers of H. opacus and C. hispidulus

\begin{tabular}{|c|c|c|c|}
\hline & $\mathbf{N}$ & Capturing date & Individuals \\
\hline \multirow{9}{*}{ Hylastes opacus } & 1 & 12 May & 14 \\
\hline & 2 & 13 May & 1 \\
\hline & 3 & 13 May & 24 \\
\hline & 7 & 15 May & 4 \\
\hline & 8 & 26 May & 17 \\
\hline & 9 & 14 May & 1 \\
\hline & 11 & 30 June & 11 \\
\hline & 12 & 26 July & 7 \\
\hline & Total & & 79 \\
\hline \multirow{6}{*}{ Crypturgus hispidulus } & 4 & 1 July & 1 \\
\hline & 5 & 27 August & 1 \\
\hline & 6 & 13 May & 1 \\
\hline & 10 & 15 May & 1 \\
\hline & 11 & 30 June & 2 \\
\hline & Total & & 6 \\
\hline
\end{tabular}
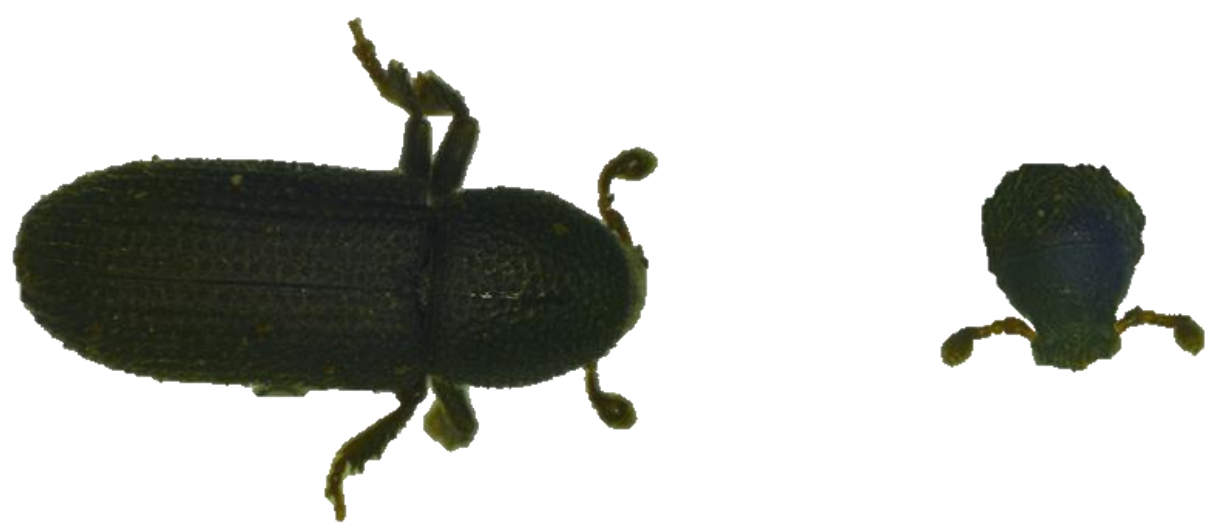

Figure 2. Hylastes opacus Erichson

We obtained only six adult of $C$. hispidulus individuals from log traps in Balıkesir and Çanakkale province in 2014. C. hispidulus can be differentiated from other Turkish species of the genus Crypturgus (except $C$. pusillus, $C$. cylindricollis and $C$. parallelocollis) by shiny elytra and with round punctures of striae and elytral declivity with individually placed setae. It can be distinguished from $C$. pusillus by fine pronotum with sparsely punctured and elytral discs and sides with erect and long setae. It differs from C. cylindricollis and C. parallelocollis in terms of sizes (Grüne, 1979; Freude et al., 1981; Lompe, 2002; Jordal and Knížek, 2007). Its adults are 1.2-1.3 mm long and have the following features: interstriae with rows of white to light brown, short, thick and filiform setae; body black (Fig. 3).

The distribution area of $C$. hispidulus includes; Austria, Belarus, Bulgaria, Central and North European Russia, Czech Republic, Denmark, England, Estonia, Finland, 
Germany, Hungary, Italia, Latvia, Lithuania, Norway, Poland, Slovakia, Slovenia, Sweden, Switzerland, and Ukraine (GBIF, 2017; Fauna Europaea, 2018).

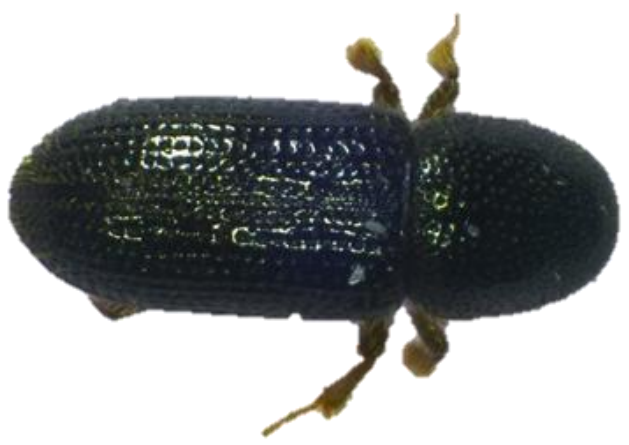

Figure 3. Crypturgus hispidulus Thomson, C. G.

There were records from Greece and Bulgaria of H. opacus. Likewise, C. hispidulus was reported from Bulgaria (Doychev and Ovcharov, 2006). Although both of them were recorded in the neighbouring countries, Hylastes opacus and Crypturgus hispidulus were recorded for the first time in Turkey. As mentioned above, the Scolytinae subfamily is represented by 135 species in Turkey. Five of those species are known only in the country. We have contributed 2 species to Scolytinae of Turkey by current article.

H. opacus breeds in the bark of stumps or at the bases of unhealthy Pinus spp., chiefly Scotch pine ( $P$. sylvestris). It occasionally infests the bark of other conifers for example Picea spp. and Larix spp. (Freude et al., 1981; Wood and Bright, 1992a; Hoebeke, 1994). We obtained H. opacus from trap logs of P. brutia and P. nigra and also pheromone traps in P. brutia stands. C. hispidulus lives under the bark of Picea, Pinus and less often on larch species. It also occurs in the galleria of other larger bark beetles for example; Xylechinus pilosus, Hylurgops palliatus, Polygraphus poligraphus, P. subopacus, Tomicus minor, Pityogenes chalcographus etc. (Freude et al., 1981). We observed that their adult individuals were associated with Orthotomicus erosus and Pityogenes pennidens on P. brutia and P. nigra log traps. Our findings are consistent with previous studies regarding the presence of adult individuals under the bark of pine species ( $P$. brutia and $P$. nigra), and the association of $C$. hispidulus with other Scolytine species.

\section{Conclusion}

Bark beetles are important disturbance agents in forestry. They can colonize weak or recently killed trees, however a few species are capable of killing healthy trees. One of the most important characteristics of bark beetles is their association with fungi. In this study, where we present two new species for Turkish fauna, our main goal was to examine the association of bark beetles-fungi. Due to the experimental design we are not able to give more detailed information for these two new species. Additional work, including their life cycle should be conducted to determine their impact on forest ecosystem. 
Acknowledgements. We would like to thank Balıkesir Regional Directorate of Forestry (Turkey) for support. We are also grateful to Mustafa Baydemir for his assistance in the fieldwork. This study was funded by Istanbul University, Scientific Research Project (project 40216).

\section{REFERENCES}

[1] Alonso-Zarazaga, M. A., Barrios, H., Borovec, R., Bouchard, P., Caldara, R., Colonnelli, E., Gültekin, L., Hlavác, P., Korotyaev, B., Lyal, C. H. C., Machado, A., Meregalli, M., Pierotti, H., Ren, L., Sánchez-Ruiz, M., Sforzi, H., Silfverberg, A., Skuhrovec, J., Trýzna, M., Velázquez de Castro, A. J., Yunakov, N. N. (2017): Cooperative Catalogue of Palaearctic Coleoptera Curculionoidea. - In: S. E. A. (ed.) Monografías electrónicas SEA 8, Zaragoza, Spain.

[2] Bright, D. E. (2014): A Catalog of Scolytidae and Platypodidae (Coleoptera), Supplement 3 (2000-2010), with Notes on Subfamily and Tribal Reclassifications. - Center for Systematic Entomology, Inc., Gainesville, FL.

[3] Cognato, A. I. (2015): Biology, Systematics, and Evolution of Ips. - In: Vega, F. E., Hofstetter, R. W. (eds.) Bark Beetles Biology and Ecology of Native and Invasive Species, Elsevier, USA.

[4] Doychev, D., Ovcharov, D. (2006): Bark Beetles (Coleoptera: Curculionidae: Scolytinae) in the Bulgarian Part of the Rhodopes. - In: Beron, P. (ed.) Biodiversity of Bulgaria. 3. Biodiversity of Western Rhodopes (Bulgaria and Greece), I. Pensoft \& Nat. Mus. Natur. Hist., Sofia.

[5] Fauna Europaea (2018): https://fauna-eu.org/cdm_dataportal/taxon/d867cbf0-76cc-4a27a949-d442e79977c7. - Accessed on 04.25.2018.

[6] Freude, H., Harde, K. W., Lohse, G. A. (1981): Die Käfer Mitteleuropas BruchidaeCurculiondae I. - Spektrum, Heidelberg.

[7] GBIF (2017): GBIF Backbone Taxonomy. Checklist Dataset. https://doi.org/10.15468/39omei. Accessed on 04.25.2018.

[8] Grüne, V. S. (1979): Handbuch zur Bestimmung der europäischen Borkenkäfer - Brief Illustrated Key to European Bark Beetles. - Verlag M. \& H. Schaper Hannover, Deutschland.

[9] Hoebeke, E. R. (1994): New records of immigrant bark beetles (Coleoptera: Scolytidae) in New York: attraction of conifer-feeding species to ethanol-baited trap logs. Entomological News 105(5): 267-276.

[10] Jordal, B. H., Knížek, M. (2007): Resurrection of Crypturgus subcribrosus Eggers 1933 stat. n., and its close phylogenetic relationship to Nearctic Crypturgus (Coleoptera, Scolytinae). - Zootaxa 1606: 41-50.

[11] Knížek, M. (1998): A new species of Pityokteines (Coleoptera: Scolytidae) from Turkey. - Klapalekiana 34: 189-193.

[12] Knížek, M., Beaver, R. A. (2007): Taxonomy and Systematics of Bark and Ambrosia Beetles. - In: Lieutier, F., Day, K. R., Battisti, A., Gregoire, J.-C., Evans, H. F. (eds.) Bark and Wood Boring Insects in Living Trees in Europe, a Synthesis. Springer, Dordrecht.

[13] Lieutier, F., Mendel, Z., Faccoli, M. (2016): Bark Beetles of Mediterranean Conifers. In: Paine, T. D., Lieutier, F. (eds.) Insects and Diseases of Mediterranean Forest. Springer, Switzerland.

[14] Lompe, A. (2002): Käfer Europas. - http://www.coleo-net.de/coleo/index.htm. Accessed on 03.13.2018.

[15] Sarkkaya, O. (2013): Notes on bark and wood-boring beetles (Coleoptera: Bostrichidae; Curculionidae: Platypodinae and Scolytinae) of the Sweetgum (Liquidambar orientalis Mill.) Forest Nature Protection Area, with a new record for Turkish fauna. - Journal of Food, Agriculture \& Environment 11(3-4): 2178-2185. 
[16] Sarkkaya, O., Avc1, M. (2011): Bark beetle fauna (Coleoptera: Scolytinae) of the coniferous forests in the Mediterrenean region of WesternTurkey, with a new record for Turkish fauna. - Turkish Journal of Zoology 35(1): 33-47.

[17] Sarıkaya, O., Knížek, M. (2013): Scolytus koenigi Schevyrew, 1890: A new record for Turkish Scolytinae (Coleoptera: Curculionidae) fauna. - J. Entomol. Res. Soc. 15(3): 9599.

[18] Selmi, E. (1987): The Hylesininae of Turkey. - Journal of the Faculty of Forestry Istanbul University A-37(1): 67-88.

[19] Selmi, E. (1998): Türkiye Kabuk Böcekleri ve Savaşı. - İstanbul Üniversitesi Yayınları, Emek Matbaacilık, İstanbul.

[20] Webber, J. F., Gibbs, J. N. (1989): Insect Dissemination of Fungal Pathogenes of Trees. In: Wilding, N., Collins, N. M., Hammond, P. M., Webber, J. F. (eds.) Insect - Fungus Interactions. Academic Press, London.

[21] Wood, S. L. (1982): Great Basin Naturalist Memoirs - The Bark and Ambrosia Beetles of North and Central America (Coleoptera: Scolytidae), a Taxonomic Monograph. Brigham Young University, Provo, Utah.

[22] Wood, S. L., Bright, D. E. J. (1992a): Great Basin Naturalis Memoirs - A Catalog of Scolytidae and Platypodidae (Coleoptera) Part 2: Taxonomic Index, Volume A. Brigham Young University, Provo, Utah.

[23] Wood, S. L., Bright, D. E. J. (1992b): Great Basin Naturalis Memoirs- A Catalog of Scolytidae and Platypodidae (Coleoptera) Part 2: Taxonomic Index, Volume B. Brigham Young University, Provo, Utah. 